\title{
端末が連携する MIMO受信技術 一理論と移動体への応用一
}

Terminal Collaborative MIMO Reception Technique: Theory and Application to Mobile Environments

村田英一 Hidekazu MURATA

梅原大祐 Daisuke UMEHARA

アブストラクト 送受信に複数のアンテナを用いて同一周波数で異なる信号を多重送信する MIMO (Multiple-Input MultipleOputput) 伝送が実用化されている．本解説ではその発展形として無線端末が連携することにより等価的なアンテナ数を拡 大し通信路容量を向上させる端末連携 MIMO 受信技術を紹介する. 端末間の連携通信には高速かつ低遅延な高周波数帯の 伝送技術の活用を想定している. 連携通信トラヒックや空間相関と伝送容量の関係を解説した後, 京都市郊外で実施した フィールド実験の結果を紹介する.

キーワード＼cjkstart端末連携，マルチューザ MIMO，チャネル容量, フィールド実験

Abstract Multiple-input multiple-output (MIMO) transmission is a practical frequency-efficient transmission technology that employs multiple transmission and reception antennas to multiplex multiple signals at the same frequency. In this paper, we describe an advanced form of MIMO transmission, in which wireless terminals collaborate with other terminals to expand the equivalent number of antennas and improve the channel capacity. We assume that the recently developed high-speed and low-latency transmission technology in high-frequency bands will be used for collaborative communications among terminals. We explain the relationship among collaboration traffic, spatial correlation, and transmission capacity, and present the results of field experiments conducted in a suburb of Kyoto City.

Key words Terminal collaboration, Multiuser MIMO, Channel capacity, Field experiment

\section{1. はじめに}

日常的に無線通信を利用してインターネットにアクセスする 社会となった。これら個人利用に留まらず，物流や建設，警備， 環境センシングから屋内での各種接続のワイヤレス化まで，無線 通信は社会を支える重要な情報インフラストラクチャとなった。 自家用車でも通信器が標準搭載され地図情報の自動更新からセ キュリティ, 緊急時の自動通報などのサービスが普及しつつあ る。このように増大し続ける無線通信トラヒックを収容するた めにこれまで，利用可能な周波数帯域の拡大，基地局やアクセ スポイント設置の高密度化，伝送技術の革新による周波数利用 効率の向上が行われてきた。本解説では周波数利用効率改善の 基盤技術といえる MIMO (Multiple-Input Multiple-Output) 伝送 ${ }^{(1)}$ に着目する。

MIMO 伝送とは同じ周波数で同時に複数の信号を伝送する 技術であり，端的にいえば混信状態での通信を行う技術である。

村田英一 正員：フェロー 京都大学大学院情報学研究科

E-mail murata@i.kyoto-u.ac.jp

梅原大祐 正員：シニア会員 京都工芸繊維大学情報工学・人間科学系

E-mail umehara@kit.ac.jp

Hidekazu MURATA, Fellow, Member (Graduate School of Informatics, Kyoto University, Yoshida-hommachi, Sakyo-ku, Kyoto 6068501, Japan), Daisuke UMEHARA, Senior Member (Faculty of Information and Human Sciences, Kyoto Institute of Technology, Matsugasaki, Sakyo-ku, Kyoto 606-8585, Japan).

電子情報通信学会 基礎・境界ソ开イエティ

Fundamentals Review Vol.15 No.3 pp.210-219 2022 年 1 月 (C)電子情報通信学会 2022
シャノンの通信路容量は SNR (Signal to Noise Ratio)のほぼ 対数（底は 2) であるため, 送信電力を倍増して SNR 2 倍に 改善しても $1 \mathrm{~b} / \mathrm{s} / \mathrm{Hz}$ 程度しか増加しない. MIMO 伝送の利点 は，複数の伝送路を利用することによりこの非効率を改善でき ることである。

MIMO 伝送が注目される以前から類似技術の研究が行われて きた。マルチユーザ受信技術(2)や干渉キャンセル技術(3)，(4)，空 間分割多重伝送技術 ${ }^{(5)}$ などである。これらは主に無線端末側が 複数存在する状況を想定していたが, MIMO 伝送は 1 対 1 伝送 の両端（基地局と無線端末）に扔いて複数アンテナを利用する ものとして登場し, 通信路容量の増大効果を理論的に解明した. その後の MIMO 伝送技術はマルチユーザ MIMO へと発展し, 複数の無線端末をも対象とする技術となったことは興味深い.

MIMO 伝送の通信路容量は送信側アンテナ数, 受信側アンテ ナ数の少ない方に比例する. しかし小型の移動端末に多数のアン テナを備えても，空間相関が増大し所期の効果が得られなくな る.このため，複数の携帯端末へ同時に MIMO 伝送を行うマル チユーザ MIMO (MU-MIMO) 伝送へとつながる. MU-MIMO 伝送を実現する代表的な方法として, 基地局において無線端末 への下り伝搬路情報を取得し，この情報に基づいて送信信号に プリコーディングを施す方法がある。しかし伝搬路が変動する 環境では，プリコーディング時に用いた伝搬路情報と送信時の 伝搬路にずれが生じるため各無線端末への信号ストリーム間に 干渉が生じ伝送特性が劣化する。

一方，無線端末が連携することによって伝送特性を向上させ 
ることが考えられてきた ${ }^{(6)}$. 具体的な検討として, セルラ方式 のダウンリンク伝送特性改善を意図したもの $(7)$, (8), アップリン ク伝送特性の改善を図るもの ${ }^{(9),(10)}$, 地上デジタル放送の受信 特性改善(11)などがある。本解説では, 無線端末が相互に連携す ることによって等価的なアンテナ数を増大させ, MIMO 伝送の 通信路容量を拡大する技術を紹介する(12) 〜 (14). この方式では 伝搬路情報のフィードバックは基本的に不要となりプリコーディ ングに見られた伝搬路変動に対する脆弱性がほぼ解消される ${ }^{(15)}$. 連携する端末間は搬送波の波長に比べて十分に離れていると考 えられるためアンテナ間相関が小さいことも期待でき, 効果的 に端末側アンテナ数を拡大できる.

端末間の連携通信用帯域として基地局との通信带域を再利用 することや別帯域を利用することが考えられる．現在，スモー ルセル用に高周波数帯の送受信機が $5 \mathrm{G}$ スマートフォンに搭載 されつつあり，スモールセル外においてこの高周波数帯を端末 連携に活用することが合理的な選択肢となる。

端末間の連携は端末が近接しており相対位置の変化が小さい 環境に適しており, 車両・電車・バス内などの移動体内への適用 が一つの有力なシナリオとなる。移動体内にあらかじめ設置さ れ給電されている無線端末と乗客の端末が連携する場合はバッ テリー消費などの問題が緩和される。一方，乗客の端末をアド ホックに連携させる場合はどのような移動体内でも連携可能と なる利点がある。また，移動体をまたいだ隣接車両間での連携 も考えられる．このようなグループモビリティは伝搬路の変動 が速いため基地局での伝搬路の把握から送信までに伝搬路が変 動することが避けられず，プリコーディング技術では対応が難 しい一方で端末連携には特に適しているものである.また，グ ループモビリティに限らず，等価的に多数の受信アンテナを有 し高い干渉キャンセル能力をもつためセル間干渉対策などとし ても端末連携は有効であると考えられる。

\section{2. 連携 MIMO 受信}

\section{1 システムモデル}

図 1 に本解説におけるシステムモデルを示す。近傍の無線端 末が連携端末グループを形成して基地局との MIMO 伝送を行 うシステムである。連携端末グループ内の端末は連携して動作 し，仮想的に 1 台の無線端末として機能する。したがって，基 地局からの信号受信だけでなく基地局への送信にも多数のアン テナを利用することができる。実際に基地局に向けてアップリ ンク送信を効果的に行うには連携端末グループ内で送信位相な どを制御することが望ましい。本解説では位相同期などの技術 課題が少なく現状の利用法ではより必要性も高いと考えられる ダウンリンクを考える。

\section{2 連携する無線端末数}

受信信号を共有するグループによって仮想的な無線端末が構 成される。このグループ内の無線端末数が多いほど MIMO 伝
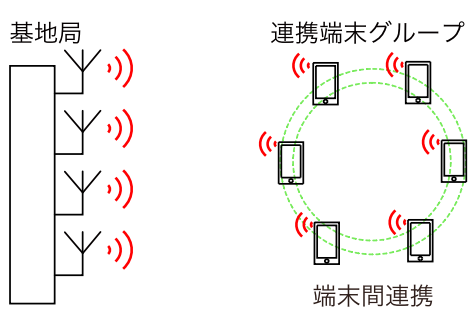

図 1 端末連携 MIMO 受信のシステムモデル＼cjkstart基地 局が送信する MIMO 多重信号を高周波数帯の 無線通信で結ばれた連携端末グループが受信す る.端末側のアンテナ数が等価的に増え通信路容 量が拡大する。

送によって得られる通信路容量が増大する。また, 同一レート で伝送している場合にはビット誤りなどの伝送品質が改善され る.このように連携端末グループ内の無線端末数は通信路容量 や伝送特性の観点からは多い方が望ましい.

多数の端末を連携させると, 連携通信に要する無線リソース (時間や周波数帯域) が増大してしまう。この連携通信は高速か つ低遅延で, できるだけ低消費電力で行えることが望ましい. このため, 連携通信は広い周波数帯域を利用して高速に, かつ, 近距離で行うことが求められる. 連携通信に利用可能な帯域幅, 伝送速度と許容される連携時間, MIMO 信号の受信状況などに 応じて連携端末数を決定する必要がある。

\section{3 端末間連携通信方式}

無線端末間の連携方式として基地局からの受信信号の一部分 や，各端末での信号処理の途中結果などを共有することも考え られるが, 本解説では各端末での受信信号全体を共有すること を考える.この場合, 共有方法は基地局からの信号の中継と同 じ動作となる。受信された 1 パケットの波形をそのまま連携端 末に向けて送信する非再生中継と, 受信サンプル值のディジタ ルデータの伝送を行うディジタル波形転送の 2 種類が考えら れる。

非再生中継では送信電力を所定值とするためにパケット全体 の振幅を調整するなどして送信することが考えられるが, 変調 方式の変更や制御情報の付加などの柔軟性が低く, 高周波数帯 送受信機に対する線形性の要求が高いなど技術的な課題がある. また, よく知られるように中継の際に熱雑音や位相雑音が累積 する.

本解説では信号共有に用いる伝送方式の自由度が高いディジ タル波形転送を考える。この方式では, 各端末が基地局からの 受信信号に対して標本化と量子化を行い, そのディジタルデー 夕を他端末に送信する。このように受信標本值のディジタル伝 送を行う場合, 量子化ビット数と連携端末数によっては非再生 中継に比べ連携通信に必要な帯域幅が増大してしまう. 


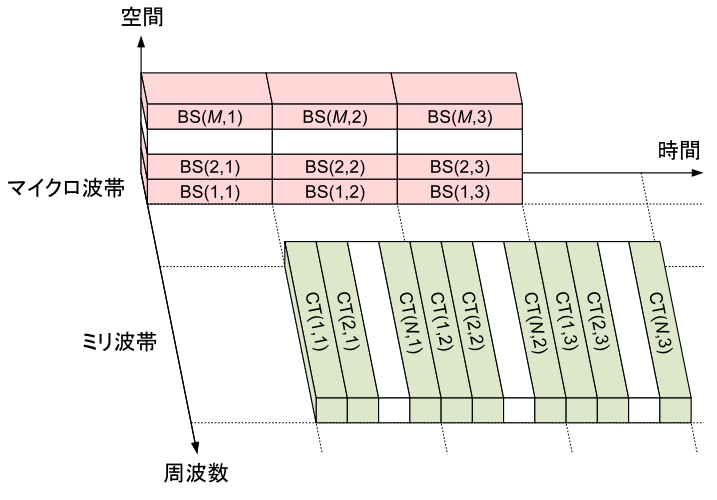

図 2 ディジタル波形転送を用いた連携 MIMO 受信の リソースブロック割当ここ図では, 基地局か ら連携端末へのダウンリンクにはマイクロ波伝 送，連携端末同士のディジタル波形転送にはミリ 波伝送を用いている。

\section{3. 連携 MIMO 受信の性能解析}

\section{1 連携 MIMO 受信のモデル化}

基地局のアンテナ数を $M$ とし，それぞれのアンテナから独 立した信号（空間ストリーム）が $K$ 台の連携端末に向けて送信 される. $i$ 番めの連携端末は $N_{i}$ 本のアンテナ素子をもち, 連携 端末のアンテナは合計して $N=N_{1}+N_{2}+\cdots+N_{K}$ 本とな る。連携端末は互いが受信した空間多重ストリームをミリ波帯 などのより高い周波数帯を用いて互いに転送し合うことで，仮 想的に $N$ 本のアンテナからなる受信アンテナアレーを構成す る。簡単のため, 各連携端末は 1 本のアンテナをもつものとす る.このとき， $N_{i}=1$ 及び $N=K$ となる. 基地局は直交周 波数分割多重 (Orthogonal Frequency Division Multiplexing, OFDM) や周波数領域等化によるシングルキャリヤブロック伝 送のような巡回プレフィックスを用いたブロック伝送方式とす る。マルチアンテナ伝送とマルチパス効果により端末で受信さ れた空間多重ベースバンド信号は，複素ガウス分布に従うとし てモデル化できる。受信波形を転送するための量子化ビット数 は，それぞれの端末で受信される空間多重信号の忠実度に関係 し，連携 MIMO 受信の性能に影響を及ぼす。

図 2 はディジタル波形転送を用いた連携 MIMO 受信のリ ソースブロック割当を示している。ここで, $\mathrm{BS}(i, j)$ は時間ス ロット $j$ に打ける基地局アンテナ $i$ からの空間ストリーム伝送, $\mathrm{CT}(i, j)$ は時間スロット $j$ に扔ける連携端末 $i$ のディジタル波 形転送のためのリソースブロックである．5G セルラーシステ ムでは $4 \mathrm{G}$ セルラーシステムで利用されている周波数帯に比較 して広い帯域幅を有する高い周波数帯が利用可能である。基地 局周波数帯の 1 時間スロットに連携端末周波数帯の $N$ 時間ス ロットが収納できるのであれば，基地局周波数帯において時間ス ロットは連続的に割り当てることが可能である。そうでなけれ ば，連携端末は高周波数帯において $N$ 時間スロットを収容する ために，量子化ビット数を少なく調整することも可能であるが， 連携端末が転送する空間多重信号の忠実度が劣化する。このた

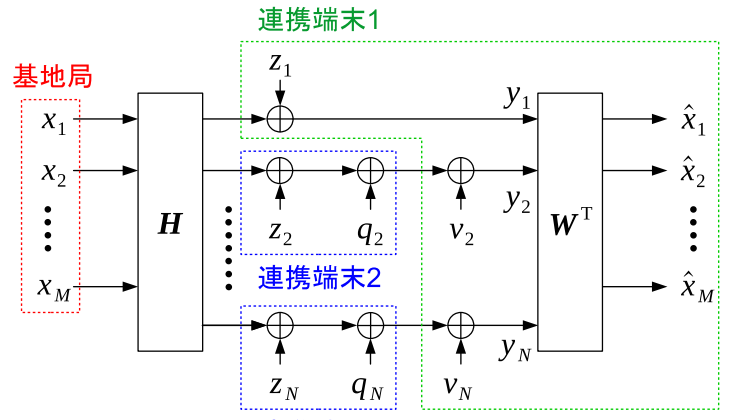

連携端末 $N$

図３＼cjkstart連携端末１に対する，ディジタル波形転送を用い た連携 MIMO 受信のサブキャリア上のベースバ ンド伝送ブロック図このブロック図では $N$ 空間多重ストリームを $M$ 空間ストリームに分割 する線形空間フィルタリングを用いている。

め, 連携 MIMO 受信の性能には, 量子化ビット数と連携端末数 との間にトレードオフが存在して，量子化誤差と空間相関の観 点から従来の MIMO 受信と連携 MIMO 受信とは異なる。した がって, 多様なシステム設計と通信路状態に対する連携 MIMO 受信の性能を評価するために性能解析モデルが必要となる。

巡回プレフイックス時間が遅延波の最大遅延時間よりも長いと 仮定する，このとき，基地局での巡回プレフィックスの付加及び 連携端末での巡回プレフィックス削除によりブロック間干渉とサ ブキャリヤ間干渉が解消される．1 本のサブキャリヤ上での伝送 に着目することで，連携 MIMO 受信は一般性を失うことなく, ブロック間干渉とサブキャリヤ間干渉がない通信路としてモデ ル化される。 OFDM 伝送の場合, サブキャリヤ上の送信サンプ ルは変調シンボルであるのに対し，シングルキャリヤブロック 伝送の場合, 送信サンプルは時間領域シンボルブロックを離散 フーリエ変換を施した周波数領域サンプルを表す.

図 3 は, 連携端末 1 に対する,ディジタル波形転送を用い た連携 MIMO 受信のサブキャリヤ上のベースバンド伝送ブ ロック図である。基地局は長さ $M$ の複素サンプルベクトル $\boldsymbol{x}=\left[x_{1}, x_{2}, \cdots, x_{M}\right]^{\mathrm{T}} \in \mathbb{C}^{M}$ を送信する.ここで, $x_{i}$ は送 信アンテナ $i$ から送信されるサブキャリヤサンプル， $A^{\mathrm{T}}$ は 行列 $\boldsymbol{A}$ の転置行列, $\mathbb{C}$ は複素数集合を表す。連携端末 $j$ は $[\boldsymbol{H} \boldsymbol{x}]_{j}=\boldsymbol{h}_{j}^{\mathrm{T}} \boldsymbol{x} \in \mathbb{C}$ を受信する.ここで, $\boldsymbol{H} \in \mathbb{C}^{N \times M}$ は $N$ 行 $M$ 列の通信路行列, $\boldsymbol{h}_{j}$ は通信路行列の転置 $\boldsymbol{H}^{\mathrm{T}}$ の $j$ 番め の列ベクトルであり, $[\boldsymbol{a}]_{j}$ はベクトル $\boldsymbol{a}$ の $j$ 番めの成分を表す. 通信路行列の $\boldsymbol{H}$ の $(j, i)$ 成分である $[\boldsymbol{H}]_{j, i}=h_{j, i}$ は, 基地局 アンテナ $i$ と連携端末 $j$ のアンテナ間のフェージング通信路係 数である. 受信サンプル $[\boldsymbol{H} \boldsymbol{x}]_{j}$ には, 受信機の熱雑音サンプル $z_{j} \in \mathbb{C}$ が付加され，この雑音サンプルは円対称複素ガウス分布 に従う。ほかの連携端末にデイジタル波形データを転送するため に, 受信サンプル $[\boldsymbol{H} \boldsymbol{x}]_{j}+z_{j}$ は高精細のアナログディジタル 変換器を経由した後に再量子化される。このとき, 周波数領域 の量子化誤差 $q_{j} \in \mathbb{C}$ が付加される．ここで，オーバーヘッドを 削減するため, ほかの連携端末にディジタル波形データを送信 する前に，巡回プレフィックスは除去される．信頼性の高いディ ジタル波形転送を実現するために，任意の物理層及びメディア 
アクセス制御 (Medium Access Control, MAC) 層の技術を利 用することができる。

連携端末 1 では, 図 3 で示されるように, 周波数領域にお いて

$$
y_{1}=\boldsymbol{h}_{1}^{\mathrm{T}} \boldsymbol{x}+z_{1}
$$

を受信する，通信路において仮に熱雑音が生じないとしても，式 （1）は劣決定系である，連携端末 1 は不十分な自由度 (Degrees of Freedom, DoF) を補うため, ほかの連携端末からディジ夕 ル波形転送により空間多重サンプルを受信する。これにより受 信サンプルベクトルは,

$$
\boldsymbol{y}=\boldsymbol{H} \boldsymbol{x}+\boldsymbol{z}+\boldsymbol{q}+\boldsymbol{v}
$$

と表される。ここで, $\boldsymbol{z}=\left(z_{1}, z_{2}, \cdots, z_{N}\right)^{\mathrm{T}}$ は各連携端末 で付加される雑音サンプルで構成される雑音ベクトル， $\boldsymbol{q}=$ $\left(q_{1}, q_{2}, \cdots, q_{N}\right)^{\mathrm{T}}$ は量子化誤差べクトル, $\boldsymbol{v}=\left(v_{1}, v_{2}, \cdots\right.$, $\left.v_{N}\right)^{\mathrm{T}}$ は連携端末 1 における転送ディジタル波形の検出誤差で ある。受信サンプル $y_{1}$ はそのまま $N$ 空間多重ストリームの復 号に用いられるため $q_{1}$ と $v_{1}$ は零である。連携端末 1 以外の連 携端末 $j$ でのディジタル波形デー夕は高周波数帯を通じて連携 端末 1 に転送されて, 連携端末 1 で元のデイジタル波形デー夕 に復元される. 高周波数带においてビット誤りが発生する可能性 があり，これらのビット誤りに起因して検出誤差サンプル $v_{j}$ と なる。しかし，ハイブリッド自動再送要求 (Hybrid Automatic Repeat Request, HARQ) や高信頼な連携端末グルーピングに より，これらの検出誤差は補償可能である。ここでは，高周波数 帯のビット誤りに起因した検出誤差は生じないと仮定する。す なわち,

$$
\boldsymbol{y}=\boldsymbol{H} \boldsymbol{x}+\boldsymbol{z}+\boldsymbol{q}
$$

となる。連携端末同士は高周波数带における高信頼通信が達成 可能な短距離通信となるため, 連携 MIMO 受信の信頼性はア ンテナ素子間の空間相関に影響を受ける。

図 3 のように, 線形空間フィルタ $\boldsymbol{W}^{\mathrm{T}}$ を利用する場合は, 周 波数領域における空間分割サンプルは，

$$
\hat{\boldsymbol{x}}=\boldsymbol{W}^{\mathrm{T}} \boldsymbol{y}=\boldsymbol{W}^{\mathrm{T}} \boldsymbol{H} \boldsymbol{x}+\boldsymbol{W}^{\mathrm{T}}(\boldsymbol{z}+\boldsymbol{q})
$$

と表される.ここで， $\hat{\boldsymbol{x}}=\left(\hat{x}_{1}, \hat{x}_{2}, \cdots, \hat{x}_{M}\right)^{\mathrm{T}} \in \mathbb{C}^{M}$ は推定送 信サンプルベクトルであり，W $\boldsymbol{W} \in \mathbb{C}^{N \times M}$ は $N$ 空間多重サン プルを $M$ 推定サンプルに分割するための重み行列である．以降 では，ディジタル波形転送を用いた連携 MIMO 受信の性能解析 モデルに量子化誤差と空間相関の効果を組み达む方法について 述べる。

\section{2 量子化雑音}

連携端末 $j$ のサブキャリヤ信号電力は,

$$
P_{\mathrm{r}}=E\left[[\boldsymbol{H} \boldsymbol{x}]_{j}\left([\boldsymbol{H} \boldsymbol{x}]_{j}\right)^{*}\right]=E\left[\boldsymbol{h}_{j}^{\mathrm{T}} \boldsymbol{x}\left(\boldsymbol{h}_{j}^{\mathrm{T}} \boldsymbol{x}\right)^{*}\right]
$$

と表される。ここで, $E[X]$ は確率変数 $X$ の平均, $a^{*}$ は複素数 $a$ の複素共役である. 時間領域と周波数領域の熱雑音サンプル は互いに独立で同一分布をもつ (independent and identically distributed, i.i.d.) 円対称複素ガウス分布に従うとしてモデル化 できる. 連携端末 $j$ のサブキャリヤ雑音電力を $2 \sigma_{\mathrm{z}}^{2}=E\left[z_{j} z_{j}^{*}\right]$ で表す。

連携端末で受信された時間領域信号は異なる振幅と位相をも つ多数の散乱波の重ね合わせである。そのため，連携端末で受 信されたベースバンド信号の分布は，中心極限定理に基づき円 対称複素ガウス分布で近似される。受信ベースバンド信号の同 相成分と直交成分の分散は,

$$
\sigma_{\mathrm{r}}^{2}=\frac{1}{2} N_{\mathrm{SC}}\left(P_{\mathrm{r}}+2 \sigma_{\mathrm{z}}^{2}\right)
$$

と表される，ここで， $N_{\mathrm{SC}}$ は基地局からのブロック伝送方式に 用いられるサブキャリヤ数である. 受信サブキャリヤ信号の電 力分布は周波数選択性フェージングにより指数分布としてモデ ル化される．総受信信号電力の変動は信号サブキャリヤ数が大 きくなるほど小さくなる，連携端末の位置の違いにかかわらず 連携端末は近距離エリア内で構成されるため, 各連携端末の総 受信信号電力は同じであると仮定する，以上のことから，同相 成分及び直交成分のサンプルが $\left[-3 \sigma_{\mathrm{r}},+3 \sigma_{\mathrm{r}}\right]$ の範囲に存在する 確率は $99.73 \%$ で近似される。

最大量子化值 $+3 \sigma_{\mathrm{r}}$ と最小量子化值 $-3 \sigma_{\mathrm{r}}$ となる一様量子化 を想定する。性能解析モデルの簡単化のため, 図 3 の受信サン プル $y_{1}$ もほかの連携端末と同様, 周波数領域の量子化誤差 $q_{1}$ が生じるとする．量子化幅は量子化ビット数 $b_{\mathrm{q}}$ を用いて,

$$
q_{\mathrm{w}}=\frac{6 \sigma_{\mathrm{r}}}{2^{b_{\mathrm{q}}}-1}
$$

と表される. $\left[-3 \sigma_{\mathrm{r}}-q_{\mathrm{w}} / 2,3 \sigma_{\mathrm{r}}+q_{\mathrm{w}} / 2\right]$ の領域外で生じる飽 和誤りはほぼ生じないため, その影響を無視する。量子化誤差 は $\left[-q_{\mathrm{w}} / 2, q_{\mathrm{w}} / 2\right]$ の範囲で一様分布となる. 同相成分と直交成 分の量子化誤差の分散は,

$$
\frac{q_{\mathrm{w}}^{2}}{12}=\frac{3 \sigma_{\mathrm{r}}^{2}}{\left(2^{b_{\mathrm{q}}}-1\right)^{2}}=\frac{3 N_{\mathrm{SC}}\left(P_{\mathrm{r}}+2 \sigma_{\mathrm{z}}^{2}\right)}{2\left(2^{b_{\mathrm{q}}}-1\right)^{2}}
$$

と導かれる. 離散フーリエ変換後の周波数領域における量子化 誤差サンプルは，時間領域の量子化誤差サンプルの重み付け和 となるため, 円対称複素ガウス分布に従うとして近似モデル化 される。連携端末 $j$ での量子化誤差の電力は,

$$
\begin{aligned}
2 \sigma_{\mathrm{q}}^{2} & =E\left[q_{j} q_{j}^{*}\right]=\frac{2}{N_{\mathrm{DFT}}} \cdot \frac{q_{\mathrm{w}}^{2}}{12} \\
& =\frac{3 N_{\mathrm{SC}}\left(P_{\mathrm{r}}+2 \sigma_{\mathrm{z}}^{2}\right)}{N_{\mathrm{DFT}}\left(2^{b_{\mathrm{q}}}-1\right)^{2}}=\frac{3 R_{\mathrm{SC}}\left(P_{\mathrm{r}}+2 \sigma_{\mathrm{z}}^{2}\right)}{\left(2^{b_{\mathrm{q}}}-1\right)^{2}}
\end{aligned}
$$

と表される. ここで, $N_{\mathrm{DFT}}$ の離散フーリエ変換のポイント数, すなわち, 総サブキャリヤ数, $R_{\mathrm{SC}}=N_{\mathrm{SC}} / N_{\mathrm{DFT}}$ は信号サブ キャリヤ率である. Lloyd-Max 量子化を利用することで, 受信 空間多重ストリームのディジタル化において量子化誤差電力を 低減することが可能である(16). アナログ信号の量子化に関する 定式化は，書籍 ${ }^{(17)}$ の 10.2 節に詳しく述べられている.

与えられた基地局周波数帯におけるサブキャリヤ信号対雑音 比 $g=P_{\mathrm{r}} /\left(2 \sigma_{\mathrm{z}}^{2}\right)$ に対して, デイジタル波形転送を用いた連携 MIMO 受信におけるサブキャリヤ信号対雑音比は 


$$
\begin{aligned}
g_{0} & =\frac{P_{\mathrm{r}}}{2\left(\sigma_{\mathrm{z}}^{2}+\sigma_{\mathrm{q}}^{2}\right)} \\
& =\frac{\left(2^{b_{\mathrm{q}}}-1\right)^{2} P_{\mathrm{r}}}{3 R_{\mathrm{SC}} P_{\mathrm{r}}+2 \sigma_{\mathrm{z}}^{2}\left(3 R_{\mathrm{SC}}+\left(2^{b_{\mathrm{q}}}-1\right)^{2}\right)} \\
& =\frac{\left(2^{b_{\mathrm{q}}}-1\right)^{2} g}{3 R_{\mathrm{SC}}(g+1)+\left(2^{b_{\mathrm{q}}}-1\right)^{2}}
\end{aligned}
$$

となる。連携 MIMO 受信における信号対雑音比の漸近的特性は

$$
\begin{aligned}
& \lim _{b_{\mathrm{q}} \rightarrow \infty} g_{0}=g, \\
& \lim _{g \rightarrow \infty} g_{0}=\frac{\left(2^{b_{\mathrm{q}}}-1\right)^{2}}{3 R_{\mathrm{SC}}} .
\end{aligned}
$$

と与えられる。式 (12) より，基地局と連携端末との通信路の信 号対雑音比が無限に漸近しても，連携 MIMO 受信の信号対雑 音比は有限となる。

\section{3 空間相関}

連携 MIMO 受信における連携端末は高周波数帯で互いに高 信頼通信が可能な近距離の端末群でグルーピングされる。連携 端末数は通信路行列 $\boldsymbol{H}$ 内の二つのフェージング係数ベクトル 間の空間相関に関係しているものと考えられる。一方で，1台 の端末で多数の受信アンテナを実装した場合と比較して，連携 MIMO 受信における空間相関を低減できる可能性がある。その ため, 空間相関は連携 MIMO 受信において効果的な端末グルー プを形成するのに有益な情報を提供する。

基地局と連携端末グループとの見通し内リンクがないものと 仮定する。このとき, 基地局と連携端末グループ間の無線通信 路は周波数選択性フェージング通信路となる。すなわち, 基地局 アンテナ $i$ と連携端末 $j$ とのフェージング係数 $h_{j, i}$ は平均 0 と 分散 1 の円対称複素ガウス分布に従う。フェージング通信路行 列 $\boldsymbol{H}$ に対して, $\boldsymbol{T}=E\left[\boldsymbol{H}^{\mathrm{H}} \boldsymbol{H}\right]$ は基地局送信アンテナ間の $M$ 行 $M$ 列空間相関行列, $\boldsymbol{R}=E\left[\boldsymbol{H} \boldsymbol{H}^{\mathrm{H}}\right]$ は連携端末の受信アン テナ間の $N \times N$ 空間相関行列と定義される。ここで， $\boldsymbol{A}^{\mathrm{H}}$ は 行列 $\boldsymbol{A}$ の共役転置である. 定義から, 空間相関行列 $\boldsymbol{T}$ と $\boldsymbol{R}$ は 半正定值エルミート行列であり, 空間相関行列のトレースはと もに $\kappa=M N$ である.

任意の送信・受信空間相関行列を与えたときにランダムに フェージング行列を生成するためにクロネッカーモデルを用い る(18), (19). 最初に, 空間相関がないフェージング行列 $\boldsymbol{G}$ をラ ンダム生成する，それらの要素の同相成分と直交成分が互いに独 立な, 平均 0 と分散 $1 / 2$ の実ガウス確率変数で生成される. 次 に，与えられた送信・受信空間相関行列 $\boldsymbol{T}$ と $\boldsymbol{R}$ に対するフェー ジング行列が

$$
\boldsymbol{H}=\frac{1}{\sqrt{\kappa}} \boldsymbol{R}^{1 / 2} \boldsymbol{G}\left(\boldsymbol{T}^{1 / 2}\right)^{\mathrm{H}}
$$

と与えられる。ここで， $T^{1 / 2}$ と $R^{1 / 2}$ はそれぞれ， $\boldsymbol{T}$ と $\boldsymbol{R}$ の 平方根行列である。 ランダムにフェージング行列を生成するモ ンテカルロ法を用いることで，ディジタル波形転送による連携 MIMO 受信における空間相関の効果を定性的に特徴付けること ができる，空間相関を有するフェージング行列を生成するため
のクロネッカーモデルは, 書籍(1)の 2.4 節に詳しく述ベられて いる.

この解説論文では，連携 MIMO 受信における空間相関の評 価に，指数空間相関行列 ${ }^{(20)}$

$$
\frac{[\boldsymbol{T}]_{i, j}}{N}=\frac{[\boldsymbol{R}]_{i, j}}{M}= \begin{cases}1, & (i=j) \\ \rho^{|i-j|}, & (i \neq j)\end{cases}
$$

を用いる。ここで， $\rho$ は 0 以上 1 未満の空間相関率である.

\section{4 伝送容量}

ディジタル波形転送を用いた連携 MIMO 通信路に扮ける伝 送容量は,

$$
C_{0}=E\left[\sum_{i=1}^{M} \log _{2}\left(\frac{\lambda_{i} g_{0}}{M}+1\right)\right],
$$

と定式化される。ここで, $\lambda_{i}$ は $M$ 行 $M$ 列の半正定值行列 $\boldsymbol{H}^{\mathrm{H}} \boldsymbol{H}$ の $i$ 番めに大きい固有值である。式 (15) は最ゆう復号 を施すことを前提としているため, 空間線形フィルタリングと は異なり送信アンテナ数 $M$ が受信アンテナ数 $N$ より多いとき にも適用可能である。送信側でフェージング行列が未知である ときの MIMO 伝送容量の定式化については, 書籍 ${ }^{(1)}$ の 3.8 節 に詳しく述べられている.

基地局の送信アンテナ数を $M=4$ 本としたときの, ディジ夕 ル波形転送を用いた連携 MIMO 受信の伝送容量を数值解析に より評価する。ここでは, ブロック伝送時に量子化誤差が最大 になるケース，すなわち，信号サブキャリヤ率が $R_{\mathrm{SC}}=1$ とな るケースを取り扱う. 与えられた信号対雑音比 $g$, 空間相関率 $\rho$ に対して，100,000 個のフェージング行列をランダム生成する モンテカルロ法を適用する.

図 4 は, 与えられた空間相関率 $\rho=0.0$ に対して, 基地局と 連携端末間の信号対雑音比 $g=P_{\mathrm{r}} /\left(2 \sigma_{\mathrm{z}}^{2}\right)$ に対する伝送容量 $C_{0}$ を示している。ここで, 連携端末数と量子化ビット数との積が $N b_{\mathrm{q}}=24$ ビットとなる四つのケース $\left(N, b_{\mathrm{q}}\right)=(6,4),(4,6)$, $(3,8),(2,12)$ の伝送容量を比較している. すなわち, 高周波数 帯において転送されるディジタル波形データ量が同一の組み合 わせを比較している。連携端末数が増加すれば複数の受信アン テナによるダイバーシチ利得が向上して低信号対雑音比の領域 において伝送容量は改善するものの, 量子化ビット数の低下に 伴う伝送容量の飽和が観測される。この図から, 最大の伝送容 量を与える連携端末数と量子化ビット数のペアは信号対雑音比 に依存することが分かり，そのときの短期的に観測される信号 対雑音比に応じて最適な連携端末数と量子化ビット数のペアを 選択する適応的な最適制御の研究課題が見い出すことができる.

図 5 は, 空間相関率 $\rho=0.8$ となるアンテナ間の空間相関が 高いときに拈ける, 信号対雑音比 $g$ に対する伝送容量 $C_{0}$ を示 している. 図 4 と同様に, 連携端末数と量子化ビット数との積 が $N b_{\mathrm{q}}=24$ ビットである四つのケースにおける伝送容量を比 較している. 図 4 と比較して空間相関による劣化を受けている ことが分かる．また，最適となる連携端末数と量子化ビット数 


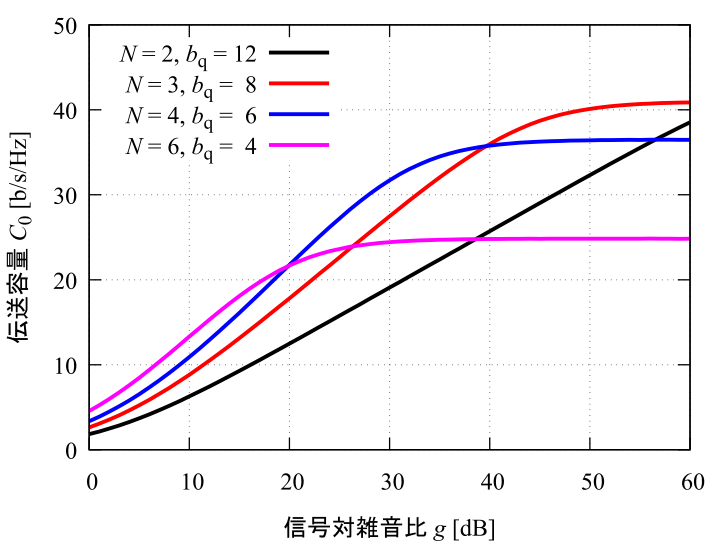

図 4 空間相関率 $\rho=0.0$ を与えたときの信号対雑音 比に対する伝送容量＼cjkstart連携端末数と量子化ビッ 卜数との積は等しく 24 ビットである.すなわち, 受信ディジタル波形の転送データ量は等しい.

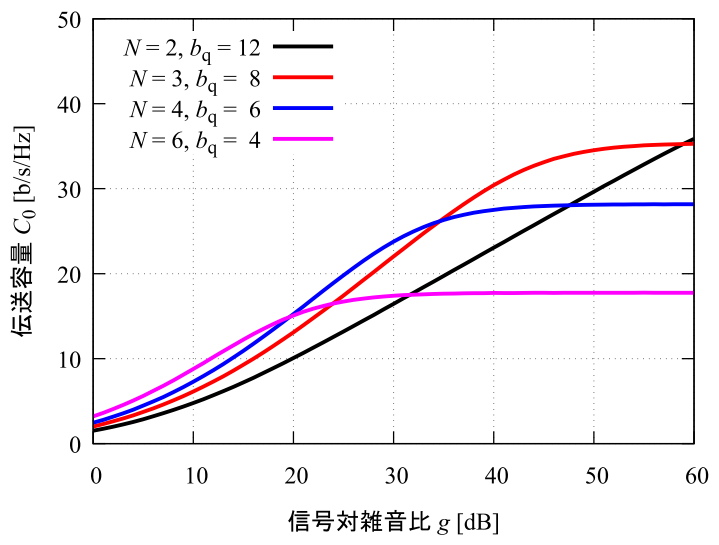

図 5 空間相関率 $\rho=0.8$ を与えたときの信号対雑音 比に対する伝送容量連携端末数と量子化ビッ 卜数との積は等しく 24 ビットである.すなわち, 受信ディジタル波形の転送デー夕量は等しい.

のペアの信号対雑音比の領域は図 4 と図 5 では異なり, 伝送容 量の最大化は信号対雑音比たけではなく空間相関率にも依存す る。そのため，短期的に観測される空間相関率に応じた適応的 な最適制御が有効である.

\section{4. フィールド実験}

実際に近い環境において連携 MIMO 受信の伝送容量改善効 果を調べるために車両に端末を積載してフィールド実験を行っ た.この実験では, 基地局から MIMO 空間多重信号を送信し, 車両ルーフ上に設置したアンテナで受信する。受信アンテナは それぞれ端末装置に接続されており, 端末間は高周波数帯にお いて相互に連携可能である。

\section{1 伝送実験システム}

伝送実験システム ${ }^{(21)}$ の構成を図 6 に示す。送信アンテナ数を $M=4$, 受信端末数を $N=6$ として, 4 ストリームの MIMO 空間多重送信を行う。受信信号の復調方式として周波数領域繰り

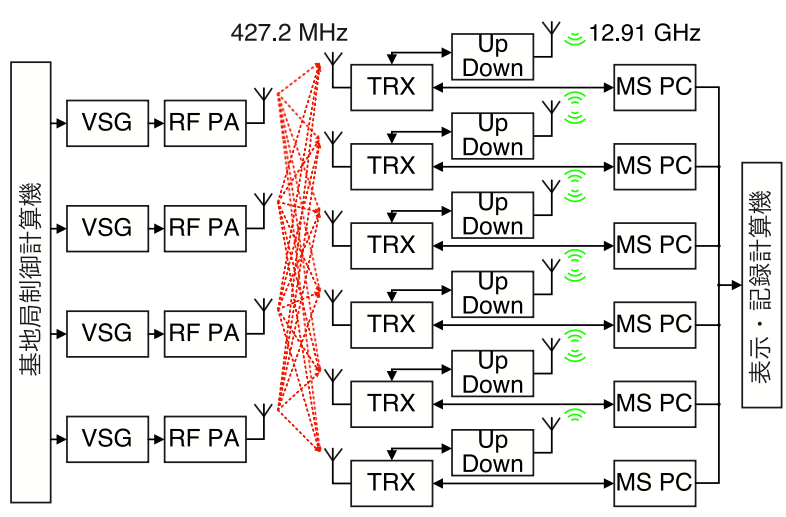

図 6 フィールド実験に用いた実験システムの構成 計算機で計算された四つの送信波形がベクトルシ グナルジェネレータ (VSG) で生成され増幅され て送信される，受信側は 6 端末で構成され，本 解説では各端末で記録された受信信号を利用し て伝送容量を計算する。

返し等化が可能である ${ }^{(22)}$. 基地局は QPSK 変調されたパケッ トを $50 \mathrm{~ms}$ ごとにキャリヤ周波数 $427.2 \mathrm{MHz}$ において 4 本の 送信アンテナから独立に送信する. 高周波電力増幅器 (図中 $\mathrm{RF}$ $\mathrm{PA})$ によって $1 \mathrm{~W}$ に増幅されており, 特定実験試験局として 免許されている. 各送信アンテナから送信されるパケットは直 交トレーニング系列とデー夕部などから構成されている。この パケットを 6 台の端末（図中 TRX）で受信し, 受信された直交 トレーニング系列部に基づいてチャネル推定を行った。受信端 末としては端末制御用計算機（図中 MS PC）で制御されたソ フトウェア無線端末である USRP (Universal Software Radio Peripheral) X310を用いた。

本装置は基地局から受信した信号波形をディジタルデータとし て他端末にデイジタル波形転送を行うことも, 非再生中継を行う ことも可能である. どちらでも基地局からの受信信号はパケット 全体について複素ベースバンドのディジタル值がメモリにいった ん保存され, 周波数変換器（図中 Up Down）を経て $12.9 \mathrm{GHz}$ 帯で送受信される。今回はディジタル波形転送を用いて復号動 作をリアルタイムに確認しつつ実験を行った。受信端末の周波 数基準には共通の GPSDO (GPS Disciplined Oscillator)を 用いた。 基地局もGPSDO を用いており, 1PPS (Pulse Per Second）により送受信の夕イミング同期も行っている.

今回の装置ではリアルタイムでの復調処理が可能であるが, 詳細な検討を可能にするために基地局からの受信信号を各受信 端末が記録した。記録はベースバンド I, Q サンプル值それぞれ 16 ビットである。記録されたこのベースバンド信号のトレーニ ング部を用いてチャネルを推定し伝送容量を算出する。端末制 御用計算機は有線 LAN で表示・記録用計算機に接続されてお り, 各端末の受信電力や復号誤り数などがリアルタイムに表示 されつつ記録される。

\section{2 屋外伝送実験}

図 7 に示す京都大学構内の建物の屋上にある 4 本の基地局ア 


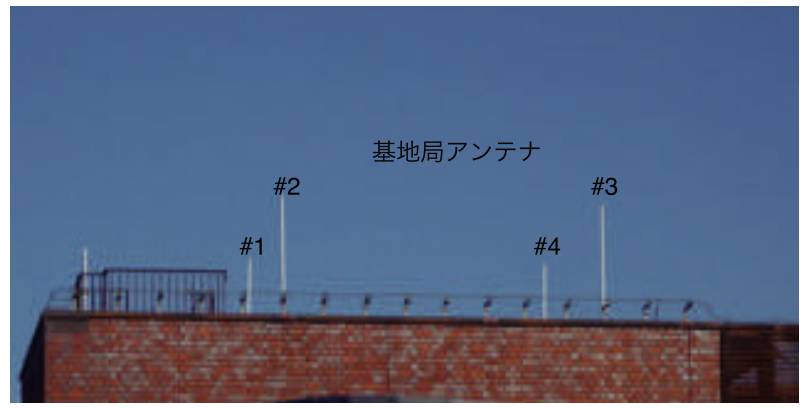

図 7 基地局アンテナ 地上高 $25.5 \mathrm{~m}$ の場所に南北 $2.5 \mathrm{~m}$ ，東西 $3.8 \mathrm{~m}$ の間隔で 4 本を設置した.

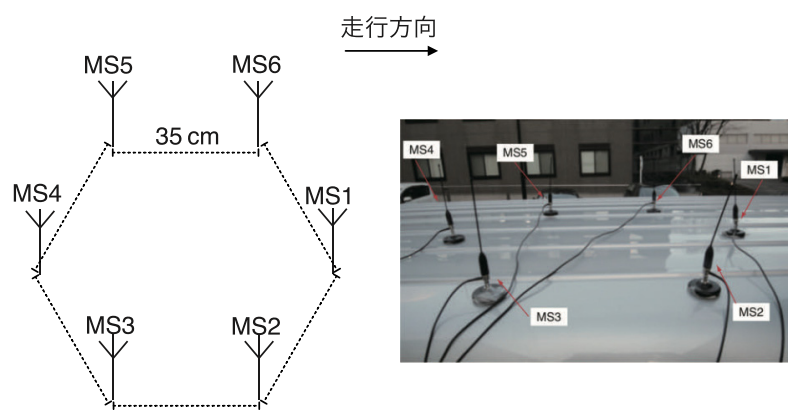

図 8 車両のフール状に設置した受信アンテナ＼cjkstart半径 が半波長の円周上に均等に配置し UCA（Uniform Circular Array) とした.

ンテナ（地上高 $25.5 \mathrm{~m}$ ，配置は $3.8 \mathrm{~m} \times 2.5 \mathrm{~m}$ の長方形状）か ら信号を送信した，基地局アンテナには水平面内無指向性グラ ンドプレーンアンテナ（ノンラジアル）を用いた．基地局から の信号は図 8 に示すように車両ルーフ上に設置した $\lambda / 4$ モノ ポール (430 MHz，水平面内無指向性) アンテナで受信した.

車両は京都市左京区の白川通りを北上した。走行コースの地 図を図 9 に示す．基地局からの受信電力は走行開始場所近くの 最大 $-45 \mathrm{dBm}$ から最低 $-99 \mathrm{dBm}$ の範囲で変化した。実験諸 元を表 1 に示す.今回の伝搬路は周波数選択性フェージング伝 搬路であるため周波数領域を 32 分割して伝送容量を求めた。こ の計算にあたってはソフトウェア無線機の雑音指数（メーカ測 定值）から雑音電力を決定している。この雑音電力はフェージ ングエミュレータを用いた伝送実験時の雑音電力とほぼ一致し ていた。

\section{3 測 定 結果}

測定コース全体について伝送容量の経験的累積分布関数 ECDF (Empirical Cumulative Distribution Function) を計算した。 伝送容量計算に用いる受信アンテナ数 $N$ を 1 から 6 まで変化 させた $\mathrm{ECDF}$ を図 10 に示す。この図より受信アンテナ数 $N$ の増大に伴って伝送容量が向上することが分かる．特に送信ス トリーム数と同数の受信アンテナ数までは大きく向上している. 受信アンテナ数が送信ストリーム数を超えても向上するが向上 幅は減少している。

ディジタル波形転送時の量子化ビット数の影響を図 11 に示す.

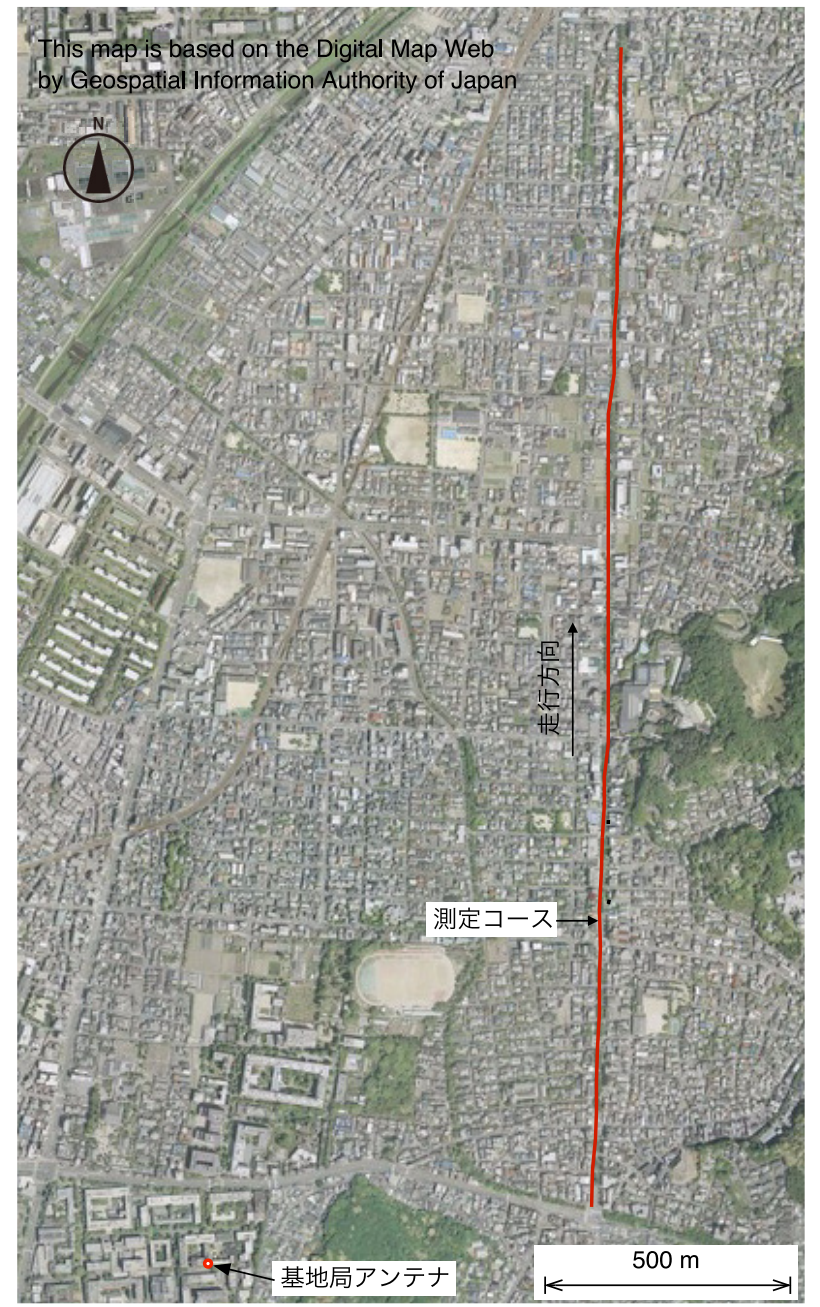

図 9 屋外伝送実験の走行コース＼cjkstart左下部の基地局か ら送信し，赤で示されたコースを北上した。

表 1 屋外伝送実験の実験諸元

\begin{tabular}{lr}
\hline Parameters & Values \\
\hline 基地局アンテナ数 & 4 \\
基地局送信電力 & $1 \mathrm{~W}$ \\
基地局アンテナゲイン & $5.8 \mathrm{dBi}$ \\
ケーブルロス & $1.4 \mathrm{~dB}$ \\
基地局アンテナ地上高 & $25.5 \mathrm{~m}$ \\
搬送波周波数 & $427.2 \mathrm{MHz}$ \\
変調速度 & $312.5 \mathrm{ksymbols} / \mathrm{s}$ \\
送信フィルタ & Square root raised cosine \\
& Roll-off factor 0.4 \\
フレーム間隔 & $50 \mathrm{~ms}$ \\
\hline 端末数 & 6 \\
端末アンテナ数 & 1 \\
端末アンテナ高 $(427.2 \mathrm{MHz})$ & $2.1 \mathrm{~m}$ \\
端末間通信周波数 & $12.91 \mathrm{GHz}$ \\
端末間通信変調速度 & Square root raised cosine \\
端末間通信フィルタ & Roll-off factor 0.4 \\
& $10 \mathrm{~mW}$ \\
端末間通信送信電力 & S
\end{tabular}

受信アンテナ数は 6 とし, 量子化ビット数を 3 から 10 まで変 化させた場合の ECDF 特性である. 比較のためにディジ夕ル波 形転送時の量子化を考慮しない場合の特性を No quantization 


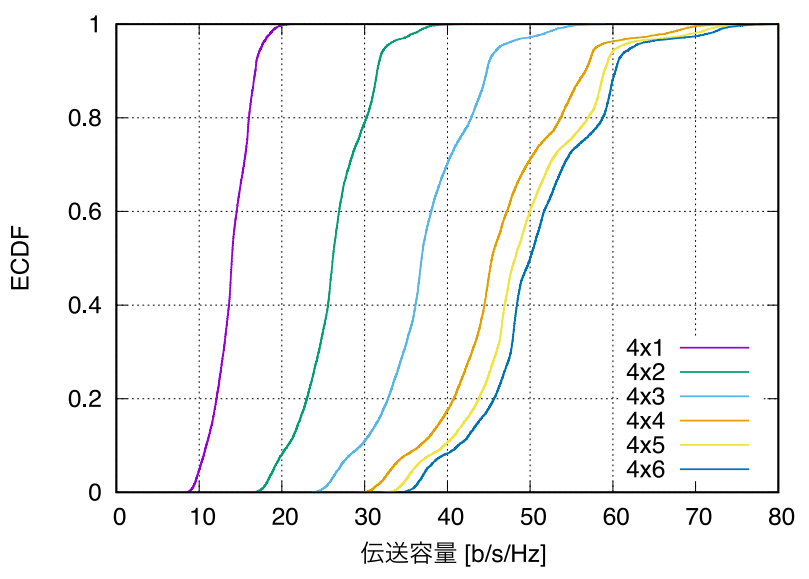

図 10 ディジタル波形転送時の量子化雑音が存在しな い場合の伝送容量の経験的累積分布関数 4 ストリーム送信に対して受信アンテナ数 $N$ を 1 から 6 まで変化させている.

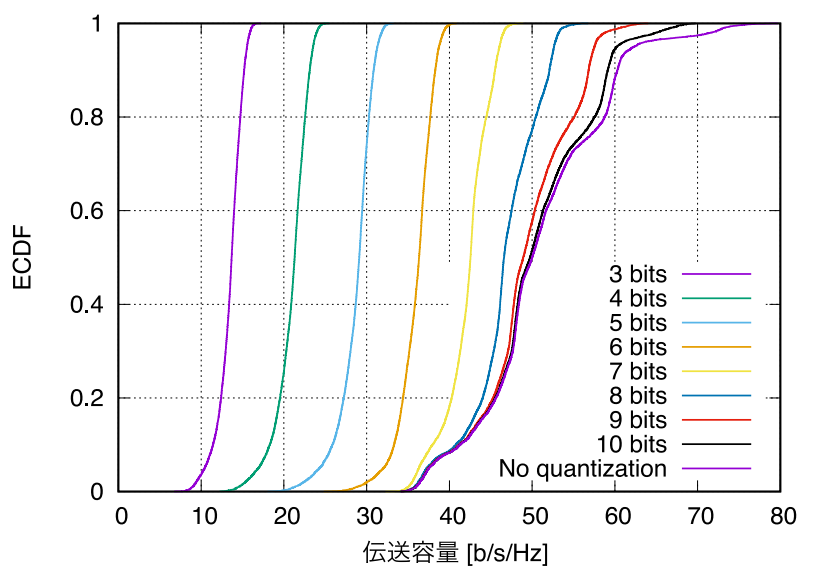

図 11 ディジタル波形転送時の量子化ビット数を変化 させた場合の伝送容量の経験的累積分布関数 基地局 4 ストリーム送信 6 アンテナ受信.

として示す．量子化ビット数が少ないと伝送容量の劣化が大き いことが分かる. 今回の測定コースでは走行開始地点の SNR が $60 \mathrm{~dB}$ 以上得られており，この大きな SNR を活かすために は 10 ビット程度の量子化ビット数が必要であったことが読み取 れる。

今回の測定コースでの結果から，端末連携による伝送容量改 善効果は次のようにまとめることができる，連携せずに 1 端末 で受信した場合の伝送容量が最大でも $20 \mathrm{~b} / \mathrm{s} / \mathrm{Hz}$ 程度であった ところ，6 端末が連携した場合最大で $70 \mathrm{~b} / \mathrm{s} / \mathrm{Hz}$ 以上の伝送容 量が得られた。 また，基地局信号の高い SNR を活かすには多く の量子化ビット数が必要となる.

\section{5. 研 究 課題}

本解説ではここまでディジタル波形転送における量子化ビッ 卜数と連携端末数, 並びにそれら端末で得られた信号の相関を 議論した。このほかにも端末が連携して基地局と通信を行う端 末連携 MIMO 受信技術には多くの研究課題がある.

\section{1 連携端末グループの形成}

連携端末数を確保するために離れた端末と連携を行うと, 連 携用送信電力の増大または連携通信速度の低下が生じる。特に, 各端末が基地局から受信した信号を連携端末グループ内の全端 末に送信する場合，この信号を受信する端末との全連携リンク 中，最もSNR が低いリンクに合わせた適応変調・適応符号化を 行うことになり, 大きな非効率が生じかねない。このため, 連 携端末グループにどの端末を含めるかの判断は連携リンクの状 況を考慮する必要がある。このように, グループ内の端末はそ れらが受信している基地局からの受信信号の SNR 等とそれら 受信信号の相関だけでなく, 端末間の通信状態をも考慮して最 適化される必要がある。

このように, MIMO 受信特性を最適化する目的であっても, 基地局信号の受信状態だけでなく端末間の通信状態を考慮する 必要がある. 加えて, 近傍に複数の連携端末グループが形成さ れている状況では, 境界付近の端末をどちらのグループに割り 当てるかは端末連携グループ独立には決定できない問題となる.

\section{2 信号処理端末の選定}

連携端末グループ内において MIMO 受信信号処理を行うこ とになるが，どの端末がこの信号処理を行うかについても自由 度がある，複数の端末宛の情報が多重されていた場合, 宛先端 末が個々に信号処理を行うことも可能であるし，特に非線形の 信号処理によって全ストリームを復号する場合ではグループ内 の 1 端末が全宛先端末分の復号を行うことが効率的となる。こ のように，信号処理方式によって信号処理端末の選び方も変わ り, そこには, ほかの端末との連携リンク状態や信号処理能力, バッテリー残量なども関係することになる。

\section{3 端末連携グループ間の干渉}

端末連携が普及した場合, 端末連携グループ相互の干渉を回 避する必要がある. 端末の動きが比較的少ない場合には, 相互 の干渉を検知して周波数帯域や時間スロットを棲み分けるなど の対応が容易である.しかし, 駅での乗降やバスターミナルな どの環境では高度な干渉回避と高速なグループ再形成が求めら れると考えられる。一方, 連携の失敗によって受信信号処理に 利用できる受信信号数が減少しても必ずしも復号誤りにつなが らないことも考えられる. 無線端末の連携を柔軟に行うことで このような問題に対応できる可能性がある.

\section{4 信号共有数の適応化}

信号共有グループ内の全端末からの受信信号を全て利用しな くても基地局からの MIMO 復号に成功する可能性がある。し たがって，信号共有グループ内の端末が順に他端末へ基地局か らの受信信号を送信する場合，何らかの中止信号などによりそ 
れ以上の信号共有を行わずに済ませることも可能である，信号 共有に要する電力消費を削減できる可能性があるが，復号を何 度も試みることになるため, 判断方式, 制御方式の検討が必要 である。

\section{5 MIMO 復号の簡易化}

端末連携 MIMO 受信では端末連携のための送受信を行うた め消費電力が増大すると考えられる。また，一般に多重数の多 い MIMO 復号ではその復号処理に要する信号処理電力も増大 するであろう。一方で，受信アンテナ数が増大すれば簡易な信 号処理によって MIMO 受信が可能となることも知られている. このため, 連携端末数を増大させ MIMO 復調処理を簡易化す ることにより全体としての消費電力が低減できる可能性もある.

\section{6 アップリンク送信電力の削減}

連携端末グループから基地局への送信を考えた場合，連携端 末群の送信位相を制御しアレー利得により送信電力を低減でき る可能性がある。また，基地局との伝搬環境が端末ごとに異な る可能性が高いことを利用し，良好な条件の端末からアップリ ンク送信を行うことで送信電力を削減することも可能となる。

\section{6. むす び}

無線端末が連携することにより等価的にアンテナ数を拡大し MIMO 伝送容量を増大させる端末連携 MIMO 受信技術を紹介 した，本解説では特に，連携台数と連携波形の量子化ビット数 に着目して理論的な説明と実験も交えた評価結果を示した。端 末間の連携には高速低遅延な高周波数帯の伝送方式の利用を想 定しており，これは高周波数帯の新たな活用方法とも捉えるこ とができる．移動端末のみならず固定設置された無線機からの 支援を得る形でも利用できるため，様々なシステムに適用でき る可能性がある。

謝辞 日頃ご協力頂く岡山大学田野哲教授に感謝します。

\section{文献}

（1） 大鐘武雄，小川恭孝，わかりやすい MIMO システム技術，オー 么社, 2009 .

(2) S. Verdu, Multiuser Detection, Cambridge University Press, Cambridge, United Kingdom, 1998.

(3) H. Yoshino, K. Fukawa, and H. Sukuki, "Interference cancelling equalizer (ICE) for mobile radio communication," IEEE Trans. Veh. Technol., vol.46, no.4, pp.849861, Nov. 1997.

(4) H. Murata and S. Yoshida, "Trellis-coded co-channel interference canceller for microcellular radio," IEEE Trans. Commun., vol.45, no.9, pp.1088-1094, Sept. 1997.

(5) T. Nishimura, T. Ohgane, Y. Ogawa, Y. Doi, and J. Kitakado, "Space domain multistage interference canceller for SDMA," IEICE Trans. Commun., vol.E84-B, no.3, pp.377-382, March 2001.

(6) M. Dohler, J. Dominguez, and H. Aghvami, "Link ca- pacity analysis for virtual antenna arrays," Proc. IEEE 56th Vehicular Technology Conference, vol.1, pp.440443, Sept. 2002.

(7) R. Dabora and S.D. Servetto, "Broadcast channels with cooperating decoders," IEEE Trans. Inf. Theory, vol.52, no.12, pp.5438-5454, Dec. 2006.

8) H. Kwon and J.M. Cioffi, "Multi-user MISO broadcast channel with user-cooperating decoder," IEEE Vehicular Technology Conference, pp.1-5, Sept. 2008.

（9）青山隆太，村田英一，荒木純道，“協力送信を用いたアドホック MIMO 空間多重伝送に関する検討,”情報理論とその応用シン ポジウム, pp.291-294, Dec. 2004.

（10）斉藤裕大，小川恭孝，大鐘武雄，西村寿彦，“仮想 MIMO シス テムを用いた上り回線に扔ける周波数オフセット推定と送受信 ウェイト制御,”信学論 (B), vol.J91-B, no.9, pp.940-947, Sept. 2008.

(11) T. Okubo and M. Itami, "A study on cooperative reception of one segment ISDB-T," 2008 International Symposium on Information Theory and its Applications, ISITA2008, Dec. 2008.

（12）村田英一，“マルチユーザ MIMO システムに抽るユーザ端末 共同干渉キャンセル,”信学技報，RCS2013-20, pp.159-164， Nov. 2013.

(13) A. Maaref, J. Ma, M. Salem, H. Baligh, and K. Zarin, "Device-centric radio access virtualization for 5G networks," GLOBECOM 2014 Workshop, pp.887893, Austin, Texas, Dec. 2014.

（14）村田英一，“高周波数帯の活用によって実現する移動端末共同 多重 MIMO 通信,”信学技報, CS2019-66, pp.21-26, Oct. 2019.

(15) H. Murata and R. Shinohara, "Performance improvement of ZF-precoded MU-MIMO transmission by collaborative interference cancellation," IEICE Commun. Express, vol.4, no.5, pp.155-160, May 2015.

(16) D. Umehara, "Digital RoHR with Lloyd-Max quantization for distributed collaborative MIMO-OFDM reception," ITE Trans. Media Technol. Appl., vol.8, no.1, pp.11-17, Jan. 2020.

（17）守倉正博（編著), OHM 大学テキスト 通信方式，オーム社, 2013.

(18) J.P. Kermoal, L. Schumacher, K.I. Pedersen, P.E. Mogensen, and F. Frederiksen, "A stochastic MIMO radio channel model with experimental validation," IEEE J. Sel. Areas Commun., vol.20, no.6, pp.1211-1226, Aug. 2002.

(19) 5G; Study on channel model for frequencies from 0.5 to $100 \mathrm{GHz}, 3 \mathrm{GPP}$ TR 38.901, version 16.1.0, Nov. 2020.

(20) M. Chiani, M.Z. Win, and A. Zanella, "On the capacity of spatially correlated MIMO Rayleigh-fading channels," IEEE Trans. Inf. Theory, vol.49, no.10, pp.23632371 , Oct. 2003.

（21）荒井将弘，村田英一，“端末連携 MIMO 受信に扔ける適応端末選 択手法と実受信信号による特性評価,”信学論 (B), vol.J103-B, no.2, pp.110-118, Feb. 2020.

(22) T. Koike, H. Murata, and S. Yoshida, "Frequencydomain SC/MMSE iterative equalizer with MF approximation in LDPC-coded MIMO transmissions," IEEE 15th International Symposium on Personal, Indoor and Mobile Radio Communications, vol.24, pp.1414-1428, Sept. 2004.

(ITS 研究会提案，2021 年 6 月 4 日受付, 2021 年 8 月 30 日再受付) 


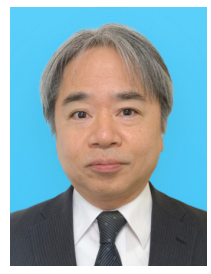

村田英一 (正員 : フェロー)

平 3 京大. 工. 電子卒. 平 5 同大大学院修士課程 了. 平 5 14 同大助手. 平 14 上り東工大助教授, 平 18 京大大学院情報学・助教授. 平 19 同准教授, 現在に至る. 工博. ワイヤレスネットワーク，無線伝 送方式の研究に従事. 平 9 本会学術奨励賞, 平 12 エリクソンヤングサイエンティストアワード, 平 16 本会功労感謝状, 平 18 電気通信普及財団テレコム システム技術賞, 平 24 同奨励賞, 平 18 科学技術分野の文部科学大臣表 彰若手科学者賞, 平 $20 \cdot 22 \cdot 28$ 本会通ソ活動功労賞, 平 $23 \cdot 25$ 本会論 文賞, 平 30 本会通ソ功労䫓彰状, 平 26 近畿情報通信協議会会長表彰, IEEE ICC 2014 Best Paper Award 各受賞.

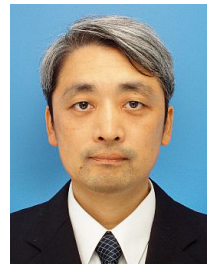

梅原大祐 (正員 : シニア会員)

1999 東京工業大学大学院理工学研究科博士後期 課程修了. 同年, 京都大学大学院情報学研究科助手. 2011 京都工芸繊維大学大学院工芸科学研究科准教授. 2016 京都工芸繊維大学情報工学・人間科学系教授. 現在に至る。 2017 年 4 月〜 2018 年 3 月, ニュー サウスウェールズ大学客員研究員. 博士 (工学)。通 信路モデル化, 変調方式, 符号化方式, メディアア クセス制御方式に関する研究に従事. IEEE 会員及び映像情報メディア学 会会員. 